\title{
Hormigones con cementos compuestos ternarios. Parte III: optimización por multicriterios
}

\section{Concretes with ternary composite cements. Part III: multicriteria optimization}

\author{
G. Menéndez ${ }^{(*)}, \underline{\text { V. L. Bonavetti }}{ }^{(*)}$ y E. F. Irassar ${ }^{(*)}$
}

Recepción/Received: 20-X-05

Aceptación/Accepted: 3-V-06

\section{RESUMEN}

Los métodos de optimización constituyen una herramienta de vital importancia en el diseño de materiales compuestos, donde la cantidad de componentes de la mezcla y los criterios de diseño que deben tenerse en cuenta en el proceso de fabricación son numerosos.

En la actualidad, la formulación de un cemento a medida (tailor made) a partir del proceso de molienda separada es un claro ejemplo de ello, pues las proporciones relativas de las componentes de la mezcla deben permitir luego obtener morteros y hormigones con el equilibrio justo entre los requerimientos durables, mecánicos, económicos y ecológicos que se soliciten.

La optimización por multicriterios ha sido empleada en el desarrollo de diversos materiales, sin embargo, su aplicación en la formulación del cemento no ha sido aún explorada. En este trabajo se presenta la optimización conjunta de la capacidad de absorción y la resistencia a compresión de hormigones elaborados con cemento Portland con caliza (hasta un 20\%) y/o escoria granulada de alto horno (hasta un 20\%) utilizando la función objetivo.

Palabras clave: cementos compuestos ternarios, caliza, escoria granulada de alto horno, optimización por multicriterios.

\section{SUMMARY}

Optimization methods are tools of vital importance in composite material design, where large numbers of components and design criteria must be taken into account.

The formulation of today's separately milled custommade cements is a clear example of just such a case, for the components must be proportioned to yield mortars and concretes with the proper balance of durability, strength, financial and environmental features.

Multicriteria optimization has been used to develop many materials, although its application in cement formulation has yet to be explored. The present paper discusses the use of an objective function to jointly optimize sorptivity and compressive strength in limestone- (up to 20\%) and/or granulated blast furnace slag- (up to 20\%) additioned Portland cement concrete.

Keywords: ternary blend cements, limestone filler, granulated blast furnace slag, multicriteria optimization.

(*) Universidad Nacional del Centro, Olavarría (Argentina). 


\section{INTRODUCCIÓN}

El concepto de desarrollo sostenible impone la obligación de satisfacer las necesidades de la presente generación sin producir desechos, polución y el derroche de los recursos y el medio ambiente, de tal forma que las futuras generaciones tengan la posibilidad de cubrir sus propias necesidades (1). Desde hace algunos años la industria del cemento continúa incorporando y asimilando los cambios necesarios para fortalecer su desarrollo en un marco cada vez más sostenible.

Desde el punto de vista de la constitución del cemento Portland, el progresivo aumento en el uso conjunto de diferentes adiciones minerales (cenizas volantes, escorias granuladas de alto horno, caliza, humo de sílice, puzolanas, etc.) como reemplazo parcial de clínker Portland contribuye a la protección del medio ambiente, a través de la reducción en la emisión de $\mathrm{CO}_{2}$ a la atmósfera y la reducción del consumo energético, sin desmejorar sus características tecnológicas (2). Por otra parte, desde el punto de vista de su fabricación, la utilización de combustibles alternativos conduce a un menor consumo de combustibles fósiles.

No obstante, si se considera que el mayor uso del cemento se destina a la elaboración de hormigón, no es correcto pensar que una vez finalizado el proceso de fabricación del mismo se ha cumplido totalmente con las leyes destinadas a preservar el medio ambiente. También debe considerarse que las estructuras que se diseñen y construyan otorguen un comportamiento durable adecuado en función de su propia vida útil. Pues toda estructura que deba regenerarse para su rehabilitación al poco tiempo de haberse construido ocasionará un gasto extra de energía y un mayor consumo de materia prima necesario para elaborar el cemento Portland a utilizar en las reparaciones, además del aumento en la cantidad de residuos.

En consecuencia, una industria del cemento sostenible no implica una industria del hormigón sustentable $y$, por ello, la formulación de los cementos a medida debe ser tenida en cuenta en el diseño del hormigón para que éste alcance el comportamiento esperado, en relación con el tipo de estructura, el destino de la misma, el lugar de emplazamiento, la vida útil requerida, etc.

Si se considera que actualmente el cemento Portland de mayor existencia en el mercado está constituido por una mezcla de por lo menos dos o más componentes en cantidades variables, el diseño de un hormigón hoy más que nunca requiere de la utilización de métodos de optimización que incluyan los diferentes requerimientos o criterios (durables, mecánicos, económicos, ecológicos, etc.) que este material deba cumplir. La optimización por multicriterios aparece como una herramienta muy empleada en el desarrollo de diversas áreas (3-5), pero su aplicación en la formulación del cemento no ha sido aún explorada. En este

\section{INTRODUCTION}

Sustainable development is defined as the obligation to meet the present generation's needs without producing waste or pollution, dilapidating resources or damaging the environment, so as to enable future generations to meet theirs (1). Over the last few years, the cement industry has been incorporating and assimilating the changes needed to strengthen its development while intensifying its commitment to sustainability.

On the one hand, in terms of cement constituents, the steady increase in the joint use of different mineral additions (fly ash, blast furnace slag, limestone, silica fume, pozzolans and so on) as partial replacements for Portland clinker contributes to environmental protection by reducing $\mathrm{CO}_{2}$ emissions and the energy consumed, without impairing the properties of the cement produced (2). And on the other, in terms of the manufacturing process, the use of alternative sources reduces fossil fuel consumption.

Since cement is primarily employed in concrete, however, environmental legislation should not be regarded to apply solely to its manufacture. It is equally important in this respect for structures to be designed and built to meet durability requirements in keeping with their service life. Indeed, the production of Portland cement to repair or rehabilitate structures shortly after construction entails extra expenditure in energy and prime materials, not to mention the additional waste generated.

In other words, a sustainable cement industry does not necessarily generate a sustainable concrete industry. Consequently, custom-made cement formulation is a factor to be borne in mind in concrete design to ensure attainment of expected performance in light of type of structure, use, location, service life and so on.

Given that the most common Portland cement on the market consists in a mixture of at least two or more components in varying proportions, today more than ever concrete design must deploy optimization methods able to address all the (durability, strength, financial, environmental and so on) requirements or criteria that the material should meet. Multicriteria optimization is a tool widely used in the development of a number of areas (3-5), but its application to cement formulation remains unexplored. The present paper discusses joint sorptivity and compressive strength optimization in Portland 
trabajo se presenta la optimización conjunta de la capacidad de absorción y la resistencia a compresión de hormigones elaborados con cemento Portland que incluyen cantidades variables de caliza y escoria granulada de alto horno.

\section{PARTE EXPERIMENTAL}

Materiales y proporciones de la mezcla: en este trabajo se utilizó un cemento Portland sin adición (CPN) con $58 \%$ de $\mathrm{C}_{3} \mathrm{~S}$ y $2 \%$ de $\mathrm{C}_{3} \mathrm{~A}$ y dos cementos Portland con caliza (CP12F y CP18F). Los cementos tienen una resistencia a compresión a 28 días de 45,40 y $42 \mathrm{MPa}$, con una superficie específica de 321,380 y $383 \mathrm{~m}^{2} / \mathrm{kg}$ para contenidos de caliza de 0,12 y $18 \%$, respectivamente. La escoria granulada de alto horno se adicionó en peso del cemento teniendo la misma un módulo químico de $(C+M+A) / S)$ de 1,8 . El árido grueso utilizado fue piedra partida granítica con un tamaño máximo de $19 \mathrm{~mm}$ y como árido fino se usó una arena natural silícea con módulo de finura de 2,35.

Proporciones de las mezclas: con los materiales antes descriptos se elaboraron hormigones con 350 $\mathrm{kg} / \mathrm{m}^{3}$ de material cementante, relación agua/material cementante $(\mathrm{a} / \mathrm{mc})$ de 0,50 y relación árido fino/árido total de 0,45 . Los contenidos de escoria adicionados fueron: $10 \%$ y $20 \%$ en el CP12Fy $C P 18 F$; y $20 \%$ en el $C P N$. El curado de las probetas fue de 24 horas en el molde y después de desmoldadas se sumergieron en agua saturada con cal hasta cumplir la edad de ensayo de 28 días.

Metodología de ensayos: la resistencia a compresión se realizó sobre probetas cilíndricas $(10 \times 20 \mathrm{~cm})$ de acuerdo a la norma IRAM 1546. Para el ensayo de absorción capi$\operatorname{lar}(6)$, se utilizaron prismas de $10 \times 15 \times 15 \mathrm{~cm}$. Cumplida la edad de ensayo, las muestras se secaron en estufa a 105 $\pm 5^{\circ} \mathrm{C}$ durante 24 horas y luego se impermeabilizaron con una pintura bituminosa dejando un área sin cubrir de $100 \mathrm{~cm}^{2}$ perteneciente a la cara de moldeo. El criterio usado para el análisis de la velocidad de absorción fue la cantidad de agua absorbida medida por la ganancia de masa. Con los resultados obtenidos en el ensayo se calculó la tasa de absorción (S), a partir de la gráfica de agua absorbida en función de la raíz cuadrada del tiempo (7).

Los resultados obtenidos en estado fresco y endurecido de los hormigones se encuentran desarrollados y discutidos en publicaciones previas $(8,9)$.

\section{OPTIMIZACIÓN POR MULTICRITERIOS}

La optimización por multicriterios es un método que permite la búsqueda en forma racional de una solución o grupo de soluciones tales que se satisfagan simultáneamente cement concrete containing varying amounts of limestone and granulated blast furnace slag.

\section{EXPERIMENTAL PART}

Materials and mixture proportions: the materials used in this study included an unadditioned Portland cement (CPN) containing $58 \% C_{3} S$ and $2 \% C_{3} A$, as well as two limestone-Portland blended cements (CP12F and $\mathrm{CP} 18 \mathrm{~F}$ ). The 28-day compressive strength of the cements with 0, 12 and $18 \%$ limestone was, respectively, 45, 40 and $42 \mathrm{MPa}$, and their BET specific surface was 321,380 and $383 \mathrm{~m}^{2} / \mathrm{kg}$. Granulated blast furnace slag with a $(C+M+A) / S$ chemical modulus of 1.8 was added by weight of cement. Crushed granite with a maximum particle size of $19 \mathrm{~mm}$ was used as the coarse aggregate, while the fines consisted in natural siliceous sand with a fineness modulus of 2.35 .

Mixture proportions: the above materials were used to manufacture concrete with $350 \mathrm{~kg} / \mathrm{m}^{3}$ of cementitious material, a water/cementitious material $(\mathrm{w} / \mathrm{cm})$ ratio of 0.50 and a fine/coarse aggregate ratio of 0.45 . Slag was added as follows: $10 \%$ and $20 \%$ to $\mathrm{CP} 12 \mathrm{~F}$ and $\mathrm{CP} 18 \mathrm{~F}$ and $20 \%$ to CPN. Specimens were cured in moulds for 24 hours and then immersed after demoulding in lime-saturated water until reaching the test age (28 days).

Test methodology: compressive strength was found with $10 \times 20-\mathrm{cm}$ cylindrical specimens pursuant to IRAM standard 1546. Prismatic specimens measuring 10 x $15 x$ $15 \mathrm{~cm}$ were used for the capillary absorption test (6). When the test age was reached, the specimens were oven dried at $105 \pm 5^{\circ} \mathrm{C}$ for 24 hours and then waterproofed with bituminous paint except for one $100-\mathrm{cm}^{2}$ patch. The criterion used to analyze the absorption rate was the amount of water absorbed, measured as weight gain. The test results were used to plot the amount of water absorbed vs the square root of time, from which graph sorptivity (S) was calculated (7).

The results obtained for the fresh mix and hardened concrete are given in prior papers $(8,9)$.

\section{MULTICRITERIA OPTIMIZATION}

Multicriteria optimization is a method for rationally seeking a solution or group of solutions that simultaneously meet different requirements or criteria, which may be related 
diferentes requerimientos o criterios que pueden ser de índole mecánico, durable, ecológico, económico, etc. Su aplicación requiere de una apropiada selección de las funciones decisivas y de las funciones objetivo. La función decisiva es la expresión analítica que relaciona los factores del diseño con la respuesta del sistema estudiado, mientras que la función objetivo establece el rango de aceptabilidad de las respuestas involucradas en la optimización.

De acuerdo a ello, para optimizar una mezcla por multicriterios se requiere hallar previamente la función decisiva para cada uno de los criterios involucrados en el diseño. La expresión general de la función decisiva calculada a partir de un Diseño Simplex (10) para una mezcla de tres componentes $\left(X_{1}+X_{2}+X_{3}=100 \%\right)$ posee la forma de la ecuación [1]: to strength, durability or environmental, financial or other considerations. Use of the method entails the suitable selection of decision and objective functions. A decision function is an analytical expression that relates design factors to the response of the system studied, while an objective function establishes the range of acceptability of the responses obtained.

Further to the above, before multicriteria optimization can be conducted, a decision function must be defined for each of the design criteria. The general expression for the design function computed from a Simplex Design (10) for a three-component mixture $\left(X_{1}+X_{2}+X_{3}=\right.$ $100 \%)$ adopts the following form equation [1]:

$$
Y=b_{1} \mathrm{x}_{1}+b_{2} \mathrm{X}_{2}+b_{3} \mathrm{X}_{3}+b_{12} \mathrm{x}_{1} \mathrm{x}_{2}+b_{13} \mathrm{x}_{1} \mathrm{x}_{3}+b_{23} \mathrm{x}_{2} \mathrm{x}_{3}+b_{123} \mathrm{x}_{1} \mathrm{x}_{2} \mathrm{X}_{3}
$$

donde, $Y$ es el criterio, $X_{1}, X_{2}$ y $X_{3}$ representan los factores y $b_{1} \ldots b_{123}$ son los coeficientes del sistema.

Obtenidas las expresiones para cada uno de los criterios que se desea optimizar, se le asigna a cada uno de ellos una función objetivo $d_{i}\left(Y_{i}\right)$, cuya expresión adopta la forma de la ecuación [2] [3] o [4], dependiendo de si se busca maximizar, minimizar o asignarle un valor específico a dicho criterio (11), respectivamente. where $Y$ is the criterion, $X_{1}, X_{2}$ and $X_{3}$ are the factors and $b_{1} \ldots b_{123}$ are system coefficients.

Once all the expressions are obtained for the criteria to be optimized, an objective function $d_{i}\left(Y_{i}\right)$ is assigned to each, which adopts the form of equations ([2] [3] or [4], depending on whether the criterion is to be maximized, minimized or assigned a specific value, respectively (11).

$$
\begin{aligned}
& d_{i}\left(Y_{i}\right)=\left[\begin{array}{lll}
0 & \text { si } & Y_{i}(x)<L_{i} \\
\left(\frac{Y_{i}(x)-L_{i}}{T_{i}-L_{i}}\right)^{p i} & \text { si } & L_{i}<Y_{i}(x)<T_{i} \\
1 & \text { si } & Y_{i}(x)>T_{i}
\end{array}\right. \\
& d_{i}\left(Y_{i}\right)=\left[\begin{array}{lll}
1 & \text { si } & Y_{i}(x)<T_{i} \\
\left(\frac{Y_{i}(x)-U_{i}}{T_{i}-U_{i}}\right)^{p i} & \text { si } & T_{i}<Y_{i}(x)<U_{i} \\
0 & \text { si } & Y_{i}(x)>U_{i} \\
0 & \text { si } & Y_{i}(x)<L_{i} \\
\left(\frac{Y_{i}(x)-L_{i}}{T_{i}-L_{i}}\right)^{p i} & \text { si } & L_{i}<Y_{i}(x)<T_{i} \\
\left(\frac{Y_{i}(x)-U_{i}}{T_{i}-U_{i}}\right)^{p i} & \text { si } & T_{i}<Y_{i}(x)<U_{i} \\
0 & \text { si } & Y_{i}(x)>U_{i}
\end{array}\right.
\end{aligned}
$$

donde $L_{i}, U_{i}$ y $T_{i}$ representan el mínimo, el máximo y un valor determinado deseable para la respuesta $Y_{i}$, con $L_{i} \leq T_{i}$ $\leq U_{i}$, respectivamente, el exponente $p_{i}$ constituye la importancia de obtener un resultado determinado. Cuando $p_{i}=1$ la función objetivo se incrementa linealmente en dirección de $T_{i}$, para $p_{i}<1$, la función es convexa favoreciendo los where $L_{i}, U_{i}$ and $T_{i}$ respectively represent the minimum, maximum and specified desirable value for response $Y_{i}$ with $L_{i} \leq T_{i} \leq U_{i}$, while exponent $p_{i}$ provides a measure of the importance of obtaining a certain result. When $p_{i}=1$, the objective function rises linearly in direction $T_{i}$; for $p_{i}<1$ the function is convex, favouring values close 


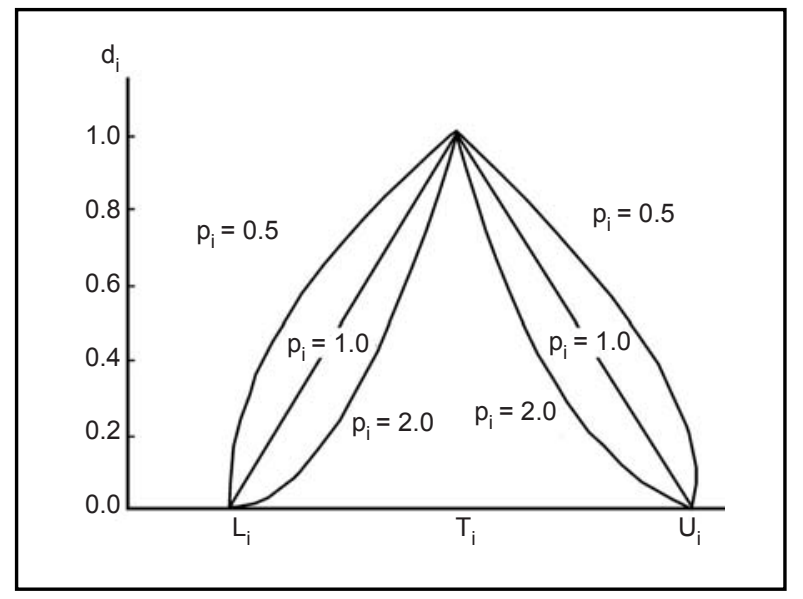

Figura 1. Funciones objetivos propuestas por Derringer (12) con diferentes pesos relativos.

Figure 1. Objective functions proposed by Derringer (12) with different relative weights.

valores cercanos a $L_{i}$ y para $p_{i}>1$, la función es cóncava y favorece los valores cercanos a $U_{i}$ (Figura 1 (12)). Esta función puede tomar valores entre 0 y $1, d_{i}\left(Y_{i}\right)=0$ representa un valor de respuesta $Y_{i}$ completamente indeseable y $d_{i}\left(Y_{i}\right)$ $=1$ representa un valor completamente deseable. La optimización de todos los criterios en forma simultánea se obtiene mediante la aplicación de la función objetivo general $D$ que vincula todos los objetivos $d_{i}$ individuales a través de su media geométrica de acuerdo a la ecuación [5]:
Tabla 1 / Table 1

Sistema de interpretación del valor del objetivo general D (13) Interpretation of the value of general objective $D$ (13)

\begin{tabular}{|l|c|}
\hline Rango / Range & Descripción / Description \\
\hline 1.00 & $\begin{array}{c}\text { El mayor nivel de satisfacción y calidad alcanzable } \\
\text { Highest attainable level of satisfaction and quality }\end{array}$ \\
\hline $1.00-0.80$ & Excelente y aceptable / Excellent and acceptable \\
\hline $0.80-0.63$ & Aceptable y bueno / Acceptable and good \\
\hline $0.63-0.40$ & Aceptable pero pobre / Acceptable but poor \\
\hline $0.40-0.30$ & Límite de aceptabilidad / Acceptability limit \\
\hline $0.30-0.00$ & Inaceptable / Unacceptable \\
\hline 0.00 & Completamente inaceptable / Wholly unacceptable \\
\hline
\end{tabular}

to $L_{i} ;$ and for $p_{i}>1$, the function is concave and favours values close to $U_{i}$ (Figure 1 (12)). The value of this function ranges from 0 to 1 , where $d_{i}\left(Y_{i}\right)=0$ represents an entirely undesirable value for response $Y_{i}$ and $d_{i}\left(Y_{i}\right)=1$ represents an entirely desirable value. Simultaneous optimization of all the criteria is obtained by applying general objective function $D$, which links all the individual objectives $d_{i}$ via their geometric mean in accordance with equation [5]:

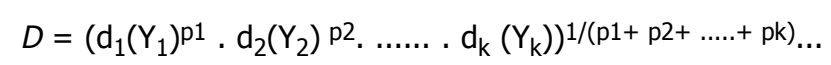

donde $p_{1} \ldots p_{k}$ representan la importancia o peso relativo de cada una de las funciones objetivos $d_{i}\left(Y_{i}\right)$. Se puede observar en la expresión que si alguna de las respuestas es completamente indeseable, el valor del objetivo general $D$ es nulo. Luego, el problema de la optimización por multicriterios se reduce a la maximización del valor $D$, que al igual que el valor individual $d_{i}\left(Y_{i}\right)$ puede variar entre 0 y 1 , donde el valor 0 indica la inexistencia de una solución tal que permita cumplir con la totalidad de los criterios, mientras que el valor 1 indica que existe una solución para el nivel de multicriterio requerido.

Para aquellos valores de $D$ distintos de 0 y 1 existe un nivel de interpretación dado por Harrington (13) para cada rango de valores como se muestra en la Tabla 1.

Por último la aplicación de esta metodología requiere:

- Ajustar un modelo para cada superficie de respuesta estudiada.

- Definir los valores individuales de la función objetivo para cada respuesta.

- Maximizar el objetivo general $D$ con respecto a los factores controlables. where $p_{1} \ldots p_{k}$ are the relative weights of the various objective functions $d_{i}\left(Y_{i}\right)$. It will be noted from the expression that if any of the responses is entirely undesirable the value of general objective $D$ is nil. Therefore, multicriteria optimization is ultimately a matter of maximizing the value of $D$ which, like the individual values $d_{i}\left(Y_{i}\right)$, may vary from 0 to 1 , where 0 indicates the nonexistence of a solution in which all the criteria can be met, whereas 1 means that a solution can be found for the multicriteria level required.

Harrington (13) divided the values of $D$ between 0 and 1 into ranges and provided an interpretation for each, as shown in Table 1.

Lastly, application of this methodology requires:

- Fitting a model for each response area studied.

- Defining the individual values of the objective function for each response.

- Maximizing general objective $D$ with respect to the controllable factors. 


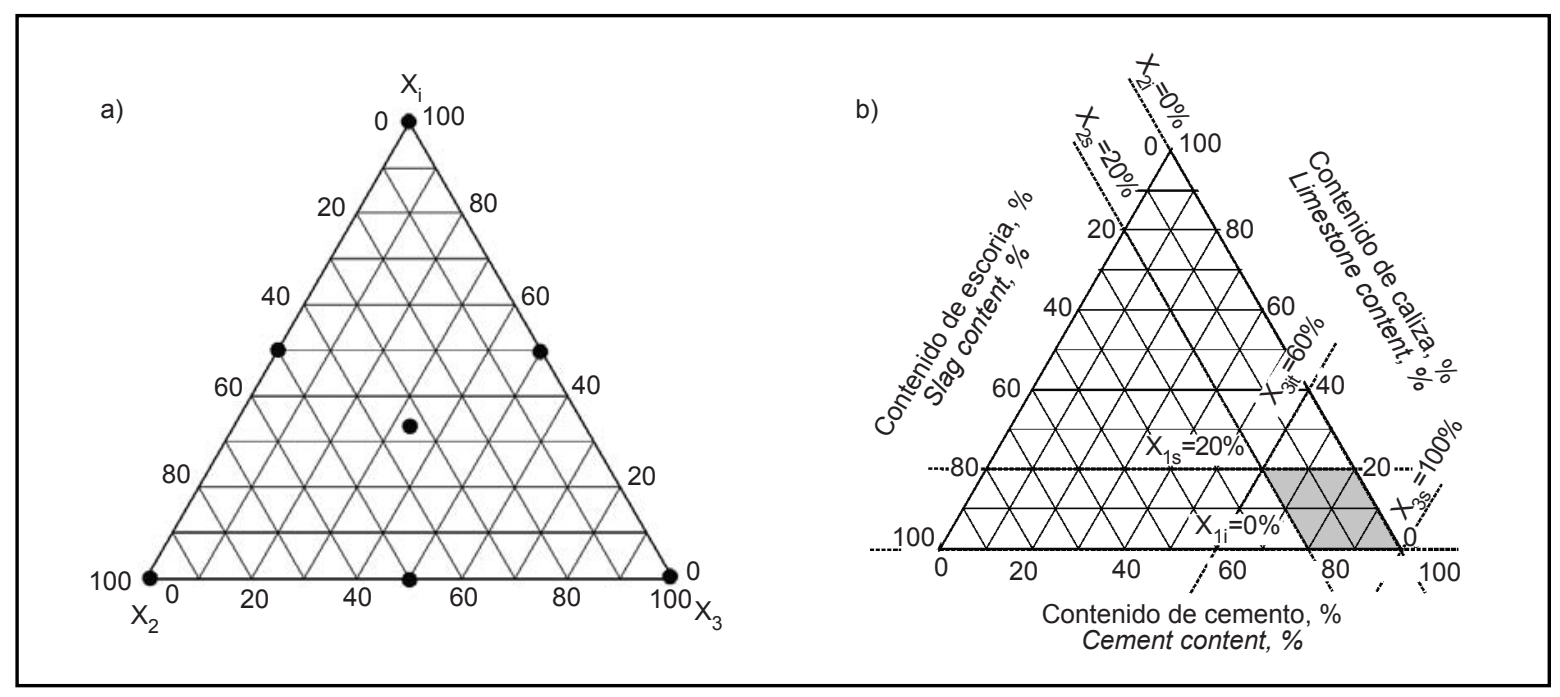

Figura 2. a) Puntos experimentales de un Diseño Simplex, b) Dominio experimental estudiado. Figure 2. a) Simplex Design experimental points; b) Experimental domain studied.

Tabla 2 / Table 2

Coeficientes de la función decisiva (ecuación [1]) para el criterio de tasa de absorción (S28) y resistencia a compresión (R28) Decision function (equation [1]) coefficients for sorptivity (S28) and compressive strength (R28) criteria

\begin{tabular}{|l|c|c|c|c|c|c|c|}
\hline \multirow{2}{*}{ Criterio / Criterion } & \multicolumn{7}{|c|}{ Coeficientes / Coefficient } \\
\cline { 2 - 8 } & $\beta_{\mathbf{1}}$ & $\beta_{\mathbf{2}}$ & $\beta_{\mathbf{3}}$ & $\beta_{\mathbf{1 2}}$ & $\beta_{\mathbf{1 3}}$ & $\beta_{\mathbf{2 3}}$ & $\beta_{\mathbf{1 2 3}}$ \\
\hline $\mathrm{S}_{28}$ & 1.81 & 1.45 & 0.10 & -9.80 & -1.87 & -1.70 & 9.81 \\
\hline $\mathrm{R}_{28}$ & -43.35 & 94.15 & 36.00 & -361.54 & 94.19 & -80.81 & 654.04 \\
\hline
\end{tabular}

\section{APLICACIÓN DEL MÉTODO}

El problema planteado en este ejemplo de aplicación consiste en hallar el conjunto de combinaciones de caliza $\left(X_{1}\right)$, escoria granulada de alto horno $\left(X_{2}\right)$ y cemento Portland $\left(X_{3}\right)$ tal que los hormigones elaborados verifiquen simultáneamente los criterios de resistencia y de capacidad de absorción a la edad de 28 días. En la Tabla 2 se presentan los coeficientes de la ecuación [1] para cada uno de los dos criterios incorporados en la optimización. Estas expresiones fueron calculadas a partir de los siete puntos experimentales que determina la aplicación de un Diseño Simplex (Figura $2 \mathrm{a}$ ) en el dominio experimental representado en la Figura $2 \mathrm{~b}$ por $x_{1}+x_{2} \leq 40 \%$, con $x_{1} \leq 20 \%$ y $x_{2} \leq 20 \%$. También se utilizó un octavo punto experimental para verificar el ajuste del modelo a través del cual se determinó que las diferencias entre los valores calculados y los valores experimentales en ningún caso superó el 5\%.

Las Figuras 3a y $3 \mathrm{~b}$ muestran las curvas de isorrespuestas de la resistencia (8) y de la capacidad de absorción (9) a 28 días, respectivamente.

Por ejemplo: se desea diseñar un hormigón H30 (resistencia característica $\left(f^{\prime}{ }_{b k}\right)$ de $30 \mathrm{MPa}$ ) con un modo 1 de control de acuerdo al nuevo Reglamento Argentino

\section{METHOD APPLICATION}

The problem posed in this sample application consists in finding the set of combinations of limestone $\left(X_{1}\right)$, granulated blast furnace slag $\left(X_{2}\right)$ and Portland cement $\left(X_{3}\right)$ with which the resulting concrete simultaneously meets 28-day sorptivity and compressive strength requirements. Table 2 gives the equation [1] coefficients for the two criteria to be optimized. These expressions were computed from the seven experimental points determined by applying a Simplex Design (Figure 2a) to the experimental domain represented by $X_{1}+X_{2} \leq 40 \%$ in Figure $2 b$, subject to $x_{1} \leq 20 \%$ and $X_{2} \leq 20 \%$ Model verification, based on an eighth experimental point, showed that the differences between the computed and the experimental values were consistently less than or equal to $5 \%$.

The strength (8) and sorptivity at 28 days (9) isoresponse contours are given in Figures $3 a$ and $3 b$.

Example: design a control mode 1 H30 concrete (characteristic strength $\left(f_{b k}^{\prime}\right) 30 \mathrm{MPa}$ ) pursuant to new Argentine code CIRSOC 201/05 (according to the code, this mode 
CIRSOC 201/05 (14) (bajo este modo, el Reglamento considera que la planta elaboradora de hormigón acredita aseguramiento de calidad) y, además, el hormigón debe registrar un índice de durabilidad excelente estimado a partir de la capacidad de absorción $(<3 \mathrm{~mm} / \mathrm{h} 0,5)$. Este límite a la tasa de absorción es especificado por Ho et al. (15), considerando una estructura que estará sometida a una lluvia de 24 horas y en la cual la penetración de agua no debe ser mayor a $15 \mathrm{~mm}$ durante este período.

El buen comportamiento del hormigón frente a los dos criterios mencionados queda definido en función de los límites admisibles que se establezcan para cada uno de ellos; conceptualmente, esto implica asegurar que la mezcla alcance una mínima resistencia a compresión y una máxima capacidad de absorción. En virtud de ello, se debe adoptar para cada criterio la función objetivo tal que maximiza la resistencia a compresión, y minimiza la capacidad de absorción, teniendo en cuenta que ambas propiedades se consideran con la misma importancia $\left(p_{i}=1\right)$. La Tabla 3 muestra los límites para cada uno de los criterios incluidos en la optimización.

Después, aplicando la función objetivo general $D$ (ecuación [5]), se obtiene la optimización de ambos criterios en forma simultánea. La Figura 4 muestra las curvas de isorrespuestas pertenecientes al valor $D$ en función de los factores $X_{1}$ y $X_{2}$ (contenido de caliza y escoria granulada de alto horno, respectivamente).

En la misma es posible observar que no existe hormigón alguno tal que satisfaga total y simultáneamente ambos criterios, pues el máximo valor que alcanza la función objetivo $D$ es de sólo 0,88 correspondiente al punto experimental $X_{1}=5 \%$ y $X_{2}=6 \%$, esto es, un hormigón elaborado con un cemento Portland conteniendo $5 \%$ de caliza y $6 \%$ de escoria granulada de alto horno. Sin embargo, existe una means that the concrete plant is quality assurance-certified) with excellent durability as estimated by its sorptivity ( $<3 \mathrm{~mm} / \mathrm{h}^{0.5}$ ). According to Ho et al. (15), at the foregoing sorptivity limit water penetration in a structure exposed to rain for 24 hours will not exceed $15 \mathrm{~mm}$.

Good concrete performance in the above respects is defined in terms of the allowable limits established for each criterion. Conceptually, this entails ensuring that the mix attains a certain minimum compressive strength and does not exceed a certain maximum sorptivity. In other words, the objective functions adopted should maximize compressive strength and minimize sorptivity, with the two properties regarded to carry equal weight $\left(p_{i}=1\right)$. The limits for the optimization criteria are given in Table 3.

Subsequently, general objective function $D$ (equation (5)) is applied to optimize the two criteria simultaneously. Figure 4 shows the iso-response contours for the value of $D$ in terms of factors $X_{1}$ and $X_{2}$ (limestone and granulated blast furnace slag content, respectively).

As the figure shows, there is no concrete able to wholly and simultaneously meet both criteria, for the highest value found for function $D$ is only 0.88 , specifically at experimental point $X_{1}=5 \%$ and $X_{2}=6 \%$ : i.e., concrete made with Portland cement containing $5 \%$ limestone and $6 \%$ granulated blast furnace slag. There is, however, a wide region where the value of the objective function

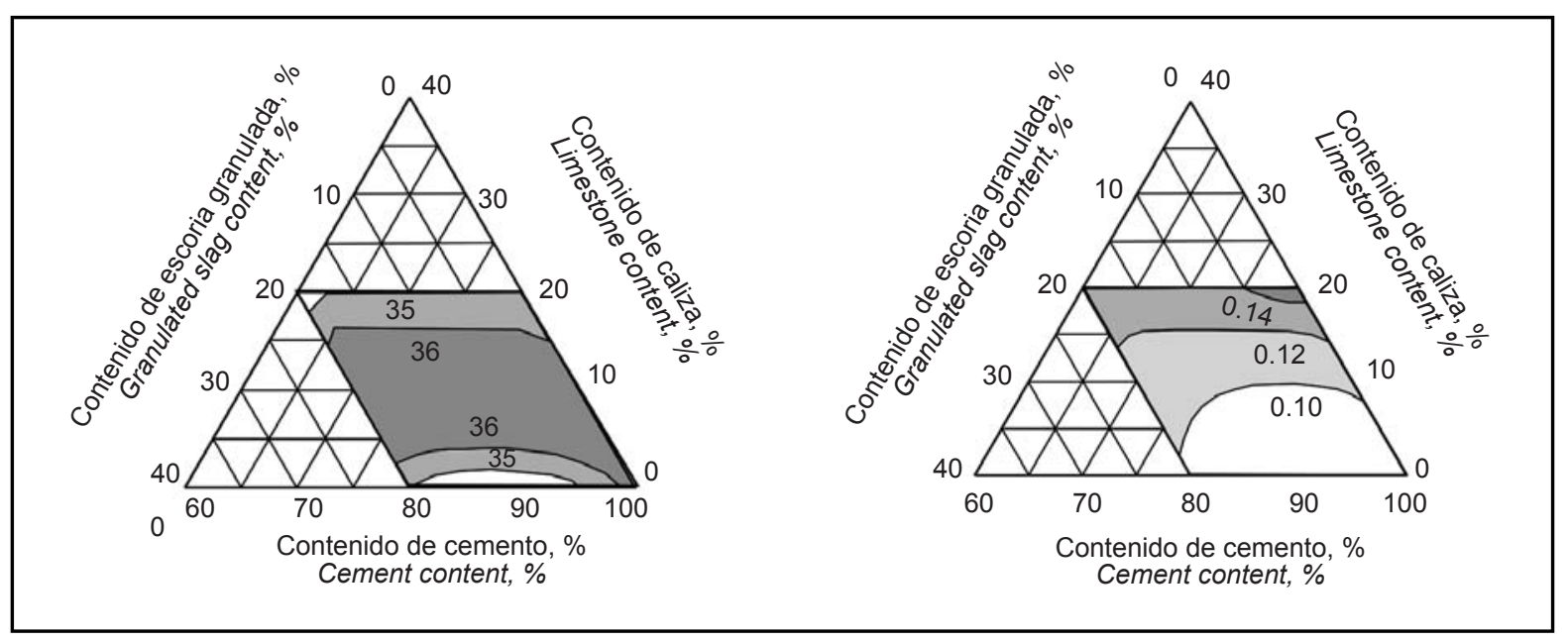

Figura 3. Curvas de isorrespuestas del dominio estudiado a 28 días. a) Resistencia a compresión y b) Capacidad de absorción. Figure 3. 28-day iso-response contours for the domain studied. a) Compressive strength and b) sorptivity. 
Tabla 3 / Table 3

Valores límites establecidos para el ejemplo de aplicación Limits established for the sample application

\begin{tabular}{|lcc|}
\hline Criterios / Criterion & Límite inferior, $\mathbf{L}_{\mathbf{i}} /$ Lower limit, $L_{i}$ & Límite superior, $\mathbf{U}_{\mathbf{i}} /$ Upper limit, $U_{i}$ \\
\hline Resistencia a compresión / Compressive strength & $34.0 \mathrm{MPa}$ & $36.9 \mathrm{MPa}$ \\
\hline Tasa de absorción / Sorptivity & $0.08 \mathrm{~g} / \mathrm{cm}^{2} \mathrm{~h} \mathrm{H}^{1 / 2}$ & $0.13 \mathrm{~g} / \mathrm{cm}^{2} \mathrm{~h}^{1 / 2}$ \\
\hline
\end{tabular}

amplia región donde la función objetivo posee un valor mínimo de 0,80 y en la cual es posible elegir una mayor gama de combinaciones de $X_{1}$ y $X_{2}$ tales que los hormigones elaborados correspondan a un rango excelente de acuerdo a la clasificación dada en la Tabla 1. El máximo reemplazo de clínker Portland para el cual aún se obtiene un hormigón con un valor de $D \geq 0,80$ se obtiene para valores de $X_{1}+$ $X_{2}$ de $22,5 \%$, con $X_{1}=5$ y $X_{2}=17,5 \%$. Luego la decisión final entre las posibles combinaciones será función de la disponibilidad y el costo de cada uno de los componentes.

Por otra parte, el valor máximo de caliza que admite dicha región es del $10 \%$ confirmando el rango óptimo de inclusión de este material establecido en trabajos anteriores (16-19). En la Figura 4b puede observarse que cuando la función objetivo $D$ es menor de 0,80 , el comportamiento de los hormigones frente a ambos criterios depende casi exclusivamente del contenido de caliza, pues las isorrespuestas ubicadas en esta zona se tornan paralelas a los contenidos de $X_{1}$.

\section{CONSIDERACIONES FINALES}

En un material como el cemento a medida que necesariamente debe satisfacer en forma simultánea los cada vez más crecientes requerimientos de los hormigones is at least 0.80 , affording a broader range of combinations of $X_{1}$ and $X_{2}$ able to produce concretes in the excellent category as per the classification set out in Table 1. The maximum replacement value of Portland clinker from which concrete with $D \geq 0.80$ can be obtained is $22.5 \%$, with $X_{1}=5 \%$ and $X_{2}=17.5 \%$. The final choice of the most suitable combination will, therefore, be based on component availability and cost.

Moreover, the maximum value for $X_{1}$ within the $D \geq 0.80$ region, $10 \%$, confirms the findings on optimum limestone content reported in previous studies (16-19). As Figure 4 shows, when objective function $D$ is under 0.80 , concrete performance in terms of both criteria depends nearly exclusively on the limestone content, for the isoresponse contours in this area are parallel to the $X_{1}$ content.

\section{FINAL COMMENTS}

In a material such as custom-made cement which must necessarily and simultaneously meet growing numbers of requirements, the use of tools to analytically determine a)

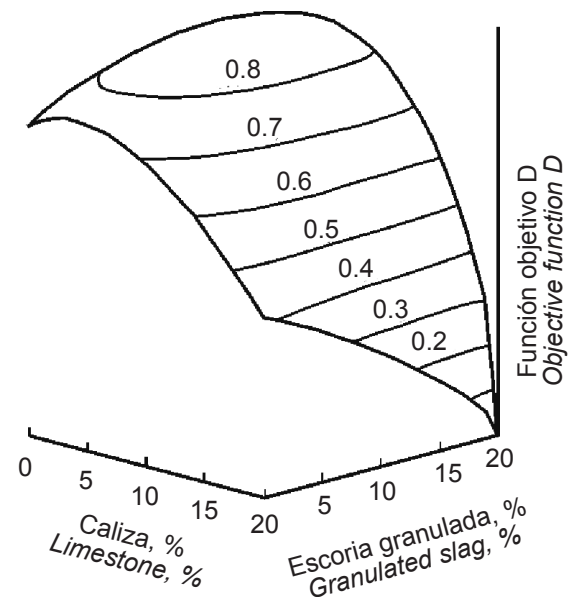

b)

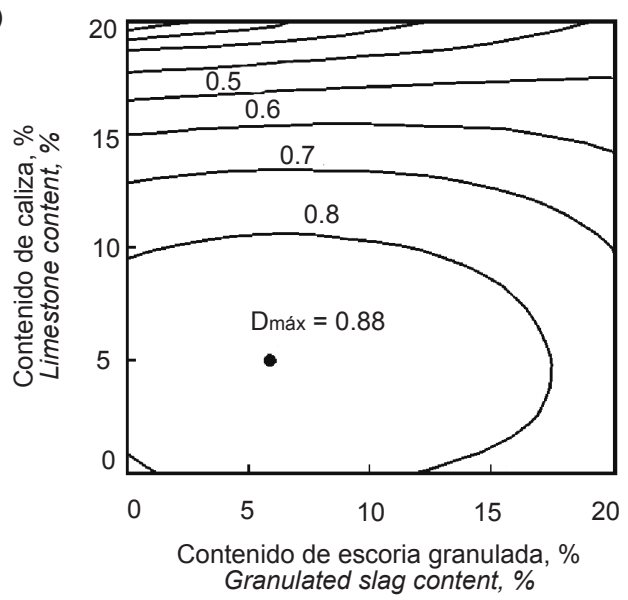

Figura 4. Curvas de isorrespuestas de la función objetivo D. a) tridimensional y b) bidimensional.

Figure 4. a) three-dimensional and b) two-dimensional iso-response contours for objective function $D$. 
que componen, hace imprescindible la utilización de herramientas que permitan hallar analíticamente su composición más conveniente. Pues, abordar dicha tarea mediante el recurso de la prueba $y$ error conduce a una extremada cantidad de trabajo experimental y en muy pocas ocasiones brinda alguna solución. Más aún, si se tiene en cuenta la amplia gama de posibilidades a partir de las diferentes combinaciones de adiciones minerales actualmente utilizadas como reemplazo parcial del clínker Portland. Adicionalmente, el empleo de la optimización por multicriterios a través de la inclusión de funciones objetivo permite encontrar combinaciones de las componentes del cemento que si bien no verifican totalmente los criterios impuestos $(D=1)$, poseen un grado de validez asociado brindado por el valor $D$.

Por último, la optimización por multicriterios en el futuro será de utilidad toda vez que el estudio de otros subproductos, que seguramente el continuo avance de la sociedad se encargará de producir, encuentren en el cemento Portland un sitio donde alojarse.

\section{AGRADECIMIENTOS}

Los autores desean agradecer el financiamiento otorgado por la Agencia Nacional de Promoción Científica y Técnica (PICT97 12-00000-01323) y la Secretaría de Ciencia y Técnica de la Universidad Nacional del Centro de la Provincia de Buenos Aires. the most suitable composition is imperative. The alternative, adopting a trial and error approach, leads to an inordinate amount of experimental work that, moreover, seldom yields a solution. The problem is accentuated by the wide variety of possible combinations of mineral additions presently used as partial replacements for Portland clinker. Furthermore, with of multicriteria optimization based on objective functions, combinations of cement components can be found that, while not wholly verifying the criteria established $(D=1)$, attain valid and acceptable $D$ values.

Lastly, multicriteria optimization will be useful in future whenever studies find Portland cement to be a viable destination for new by-products that society, in its ongoing evolution, is certain to generate.

\section{ACKNOWLEDGEMENTS}

The present study was funded by the National Agency for the Furtherance of Science and Technology (PICT97 12-00000-01323) and the Science and Technology Secretariat of the National University, Centre, of the province of Buenos Aires.

\section{BIBLIOGRAFÍA / BIBLIOGRAPHY}

(1) Swamy, R. N.: "Sustainable concrete for infraestructure regeneration and reconstruction", Proc. International Conference on Sustainable Construction. Edited by N. Barbosa, R. Swamy and C. Lynsdale (200), pp. 15-44.

(2) Malhotra, V. M.: "Role of Supplementary cementing materials in reducing greenhouse gas emissions", Proc. Int. Conference on Infrastructure Regeneration and Rehabilitation-Improving the Quality of Life through better Construction-A Vission for the Next Millennium, Ed. R.N. Swamy, Sheffield Academics Press (1999), pp. 27-42.

(3) Klemm, A. J. y Marks, W.: "Multicriteria optimisation of polymer modified composites subjected to freezing and thawing cycles", Buildings and Environment, vol. 34 (1999), pp. 368-375.

(4) Marks, W.: "Multicriteria optimisation of shape of Energy-Saving buildings", Buildings and Environment, vol. 32, no 4 (1997), pp. 331-339.

(5) Tzeng, G., Teng, M., Chen, J. y Opricovic, S.: "Multicriteria selection for a restaurant location in Taipei", International Journal of Hospitality Management, vol. 21 (2002), pp. 171-187.

(6) Camarini, G., Balayssac, J. P. y Detriché, Ch.: "Influence of cement type and curing conditions on initial absorption of concrete", Proc. $2^{\circ}$ CANMET/ACI International Conference, ACI SP-186, Gramado, Brazil (1999), pp. 427-431.

(7) Menéndez, G., Bonavetti, V. L. e Irassar, E.: "Absorción capilar en hormigones con cemento compuesto", Revista Hormigón, no 38 (2001), pp. 25-34.

(8) Menéndez, G., Bonavetti, V. L. e Irassar, E. F.: "Hormigones con cementos ternarios. Parte I: Estado fresco y propiedades mecánicas", Mater. Construcc., vol. 56, no 284 (2006), pp. 56-67.

(9) Menéndez, G., Bonavetti, V. L. e Irassar, E. F.: "Hormigones con cementos ternarios. Parte II: Mecanismos de transporte", Mater. Construcc., vol. 285, n० 285 (2007), pp. 31-43.

(10) Menéndez, G., Bonavetti, V. L. e Irassar, E. F.: "Diseños experimentales: su aplicación en la tecnología del hormigón", Revista Hormigón, no 39 (2003), pp. 17-27.

(11) Cahya, S.: Sampling properties of optimal operating conditions of single and multiple response surface systems, Thesis in Industrial Engineering, The Pennsylvania State University, 2002, p. 198. 
(12) Derringer, G. y Suich, R.: "Simultaneous optimization of several response variables", Journal of Quality Technology, vol. 12, no 4 (1980), pp. 214-219.

(13) Harrington, E. C.: The desirability function, Industrial Quality Control, abril (1965), p. 494.

(14) Reglamento CIRSOC 201: Reglamento Argentino de estructuras de Hormigón, 2005.

(15) Ho, D. W., Hinczak, I., Conroy, J. J. y Lewis, R. K.: "Influence of slag cement on the water sorptivity of concrete", Proceedings, Flay ash, silica fume, slag and natural puzzolans in Concrete. ACI SP 91-72, Madrid, España, 1986, pp. 1463-1473.

(16) Bonavetti, V. L.: Cementos con filler calcáreo. Mecanismo de interacción y su influencia sobre la resistencia, Tesis MSc. Universidad Nacional del Centro de la Provincia de Buenos Aires, 1998, p. 242.

(17) Irassar, E. F., Bonavetti, V. L., Cabrera, O., Donza, H. y Menéndez, G.: "Mechanical properties and durability of concrete made with portland limestone cement", Three-Day International Symposium on Sustainable Development and Concrete Technology, 16-19 de septiembre, San Francisco, USA. ACI Special Publication 202-27, V.M. Malhotra et al. Eds., 2001, pp. 431-450.

(18) Menéndez, G., Bonavetti, V. L. e Irassar, E. F.: "Strength development of ternary blended cement with limestone filler and blastfurnace slag", Cement and Concrete Composite, vol. 25, no 1 (2003), pp. 57-63.

(19) Carrasco, M. F., Menéndez, G., Bonavetti, V. L. e Irassar, E. F.: "Strength Optimization of "Tailor Made Cement" with Limestone Filler and Blast Furnace Slag", Cement and Concrete Research, vol. 35 (2005), pp. 1324-1331. 